\title{
MANAGEMENT AND ADMINISTRATION
}

\author{
DOI https://doi.org/10.51647/kelm.2021.7.1.24
}

\section{KONCEPCYJNE PODSTAWY KSZTALTOWANIA STRATEGII DIGITAL MARKETINGOWEJ POZYCJONOWANIA INSTYTUCJI OŚWIATOWEJ}

\author{
Irina Kanevska \\ dyrektor Połtawskiego Oddziału Uniwersytetu Europejskiego (Połtawa, Ukraina) \\ ORCID ID: 0000-0002-6293-1375
}

\author{
Mariya Hunchenko \\ kandydat nauk ekonomicznych, docent, \\ docent Katedry Zarządzania i Logistyki \\ Narodowego Uniwersytetu „Politechnika Poltawska imienia Jurija Kondratiuka” (Poltawa, Ukraina) \\ ORCID ID: 0000-0003-2488-6566 \\ Gunchenko_m@ukr.net
}

\begin{abstract}
Adnotacja. Artykuł udowodnił, że strategiczne wytyczne dotyczące usług edukacyjnych w instytucjach edukacyjnych są przede wszystkim kształtowane przez kierownika. Okazało się, że naukowcy popierają ideę zastosowania w instytucjach oświatowych koncepcji marketingu holistycznego jako modelu holistycznego planowania, opracowywania i wdrażania programów marketingowych i działań obejmujacych cztery takie elementy: marketing wewnętrzny; marketing relacji; marketing mix; marketing społeczno-etyczny. Udowodniono, że aby zwiększyć możliwości świadczenia usług edukacyjnych, warto również wdrożyć koncepcję Smart-University, która opiera się na wirtualnej przestrzeni edukacyjnej. Zbadano, że w dzisiejszym informatyzowanym środowisku istotne są trzy cyfrowe strategie marketingowe: promocja w wyszukiwarkach; reklama online; marketing w sieciach społecznościowych. Ugruntowane są koncepcyjne podstawy kształtowania strategii digital marketingowej pozycjonowania instytucji oświatowej. Udowodniono, że szybkie tempo informatyzacji, tworzenie jedności internetowej, rozgałęzienie sieci (WWW, Word Wide Web) wymaga od instytucji oświatowych opracowania własnych oficjalnych zasobów internetowych z elementem ,feedback”, skierowanych do docelowych odbiorców konsumentów.
\end{abstract}

Słowa kluczowe: komunikacja, marketing, zarządzanie marketingowe, model, usługi edukacyjne, strategia.

\section{CONCEPTUAL PRINCIPLES OF THE FORMATION OF MARKETING DIATHAL-STRATEGY POSITIONING OF THE INSTITUTION OF EDUCATION}

\author{
Irina Kanevska \\ Director of the Poltava branch of the European University (Poltava, Ukraine) \\ ORCID ID: 0000-0002-6293-1375
}

Mariya Hunchenko

Ph.D., Associate Professor at the Department of Management and Logistics

National University «Yuri Kondratyuk Poltava Polytechnic» (Poltava, Ukraine)

ORCID ID: 0000-0003-2488-6566

Gunchenko_m@ukr.net

\begin{abstract}
It is proven in the article, that strategic reference-points in relation to educational services in establishments of education near-term formed by a leader. It is found that scientists support the idea of application in educational institutions of the concept of cholistic marketing as a model of holistic planning, development and implementation of marketing programs and measures, including four such components: internal marketing; units of the educational institution; Marketing relationships; Marketing Mix; Socio-ethical marketing. It is proved that in order to expand the capabilities of providing educational services it is also worth implementing the Concept of Smart University, which is based on the virtual educational space. Researchthat three digital marketing strategies are relevant in a modern informatized environment: promotion in search engines; online advertising; Marketing in social networks. The conceptual principles of the formation of marketing diathal-strategy positioning of the institution of education. It is proved that the rapid rates of informatization, the formation of BEB community, the development of World Patina (WWW, Word Wide Web) requires institutions of education of developing its own official web resources with an element of "feedback", oriented to the target audience of consumers.
\end{abstract}

Key words: communications, marketing, marketing management, model, educational services, strategy. 


\title{
КОНЦЕПТУАЛЬНІ ЗАСАДИ ФОРМУВАННЯ МАРКЕТИНГОВОЇ ДІДЖИТАЛ-СТРАТЕГІЇ ПОЗИЦІОНУВАННЯ ЗАКЛАДУ ОСВІТИ
}

\author{
Ірина Каневська \\ директор Полтавської філії Європейського університету (Полтава, Україна) \\ ORCID ID: 0000-0002-6293-1375 \\ Марія Гунченко \\ кандидат економічних наук, доцент, \\ доиент кафедри менеджменту і логістики \\ Національного університету \\ «Полтавська політехніка імені Юрія Кондратюка» (Полтава, Україна) \\ ORCID ID: 0000-0003-2488-6566 \\ Gunchenko_m@ukr.net
}

\begin{abstract}
Анотація. У статті доведено, що стратегічні орієнтири щодо освітніх послуг у закладах освіти першочергово формуються керівником. 3'ясовано, що науковці підтримують ідею застосування у навчальних закладах концепції холістичного маркетингу як моделі цілісного планування, розроблення і впровадження маркетингових програм і заходів, що включає чотири компоненти: внутрішній маркетинг; маркетинг стосунків; маркетинг-мікс; соціально-етичний маркетинг. Доведено, що для розширення можливостей надання освітніх послуг також варто впроваджувати концепцію «Smart-університет», в основі якої покладено віртуальний освітній простір. Досліджено, що у сучасному інформатизованому середовищі актуальними є три цифрові маркетингові стратегії: просування в пошукових системах; онлайн-реклама; маркетинг у соціальних мережах. Обгрунтовано концептуальні засади формування маркетингової діджитал-стратегії позиціонування закладу освіти. Доведено, що швидкі темпи інформатизації, формування Веб-спільности, розгалуження Всесвітньої паутини (WWW, Word Wide Web) вимагають від закладів освіти розроблення власних офіційних веб-ресурсів із елементом «зворотний зв'язок», зорієнтованих на цільову аудиторію споживачів.
\end{abstract}

Ключові слова: комунікації, маркетинг, маркетинговий менеджмент, модель, освітні послуги, стратегія.

Вступ. За сучасних умов навчальні заклади перебувають у постійному пошуку нових шляхів і форм для підвищення рівня своєї конкурентоспроможності, позитивного іміджу і репутації. Для ефективного залучення здобувачів на навчання треба застосовувати маркетингові дослідження ринку освітніх послуг, зокрема вивчення освітніх потреб адресних груп, проводити успішну рекламну кампанію та здійснювати профорієнтаційні заходи протягом поточного року. Тому розвиток навчальних закладів в умовах вільного ринку зумовлює необхідність застосування розумних маркетингових комунікацій освітніх послуг. Метою таких комунікацій є вплив на інших за допомогою переконання. Сучасні здобувачі є досить вимогливими. Тому закладам освіти потрібно застосовувати сучасні інструменти маркетингових комунікацій освітніх послуг, які є засобами впливу на споживачів освітнього ринку. До традиційних інструментів маркетингу, що найчастіше використовуються на практиці, належать: реклама, збут, обслуговування споживачів, політика цін, вивчення потреб і попиту, зв'язок зі споживачами і громадськістю.

Метою дослідження $є$ обгрунтування концептуальних засад щодо формування маркетингової діджитал-стратегії позиціонування закладу освіти.

Теоретичною та методологічною основою наукового дослідження стали діалектичний метод наукового пізнання, системний підхід до вивчення економічних і соціальних явищ, наукові праці як вітчизняних, так і зарубіжних учених-економістів, у яких висвітлено питання маркетингу освітніх послуг.

Основна частина. Аналіз останніх наукових досліджень і публікацій свідчить про те, що є широка популярність соціальних медіа, яка сприяє багатьом змінам у секторі вищої освіти, включаючи діяльність із брендингу закладів вищої освіти у країнах, що розвиваються. Виходячи з теорії використання і задоволення, науковці досліджують вплив соціального бренду серед майбутніх здобувачів на позиціонування бренду закладу освіти з урахуванням спільного створення та довіри до нього як посередників і досвіду використання бренду як модератора. Кількісні результати вказують на те, що соціальна взаємодія здобувачів через соціальні медіа розвиває відмінне позиціонування бренду закладів освіти. Виявлено, що спільне створення бренду та довіра до нього опосередковують вплив соціального залучення бренду на позиціонування бренду. Окрім того, досвід використання бренду опосередковує вплив спільного створення та довіри до нього на позиціонування цього бренду (Charitha Harshani Perera, Rajkishore Nayak \& Long Thang Van Nguyen, 2020). Д. Беттіга і Л. Ламберті переконані, що концепція спільного створення бренду відноситься до процесу, який включає в себе активну співпрацю клієнтів, що мотивує клієнтів брати участь в обміні інформацією, знаннями і досвідом (Веttiga, Lamberti \& Noci, 2018). Д. Джамалі і Ч. Карам у своїй статті висвітлили основні узагальнення попередніх досліджень і зосередилися на вивченні онлайн-середовища, яке в основному розглядається іншими дослідниками в автономному режимі налаштування (Jamali \& Karam, 2018). В умовах загострення конкуренції між закладами вищої освіти (ЗВО) критичними питаннями залишаються стратегія позиціонування і рейтинг закладів. Так, Ондер Кетюда у своїй публікації «Стратегії позиціонування та рейтинги» стверджує, 
що необхідно шукати концептуальну відповідність між стратегіями позиціонування та рейтингом (Кеthüda Önder, 2021). Такий пошук насамперед спрямований на розроблення емпірично отриманої типології стратегій позиціонування для закладу вищої освіти. Так, у Великобританії контент-аналіз використовувався для аналізу веб-сторінок ЗВО для визначення баз позиціонування. У результаті було визначено нову типологію позиціонування, що складається з восьми базових позицій, які є найвищими в асортименті, таких як життєвий досвід кампусу, інтернаціоналізація, досконалість викладання, якість досліджень, перспективи випускників, місце розташування та співвідношення ціни та якості (Kethüda Önder, 2021).

Відомі науковці у сфері маркетингу підкреслюють, що придбання більшості товарів споживачами здійснюється в певній послідовності, зокрема реакцій, які приводять до прийняття рішення. Так, розроблена в 1896 р. Ел. Левісом модель AIDA для освітніх послуг є досить простою й ієрархічною для відтворення розумового процесу за ланцюжком: увага (attention) - цікавість (interest) - бажання (desire) - дія (action) (рис. 1).

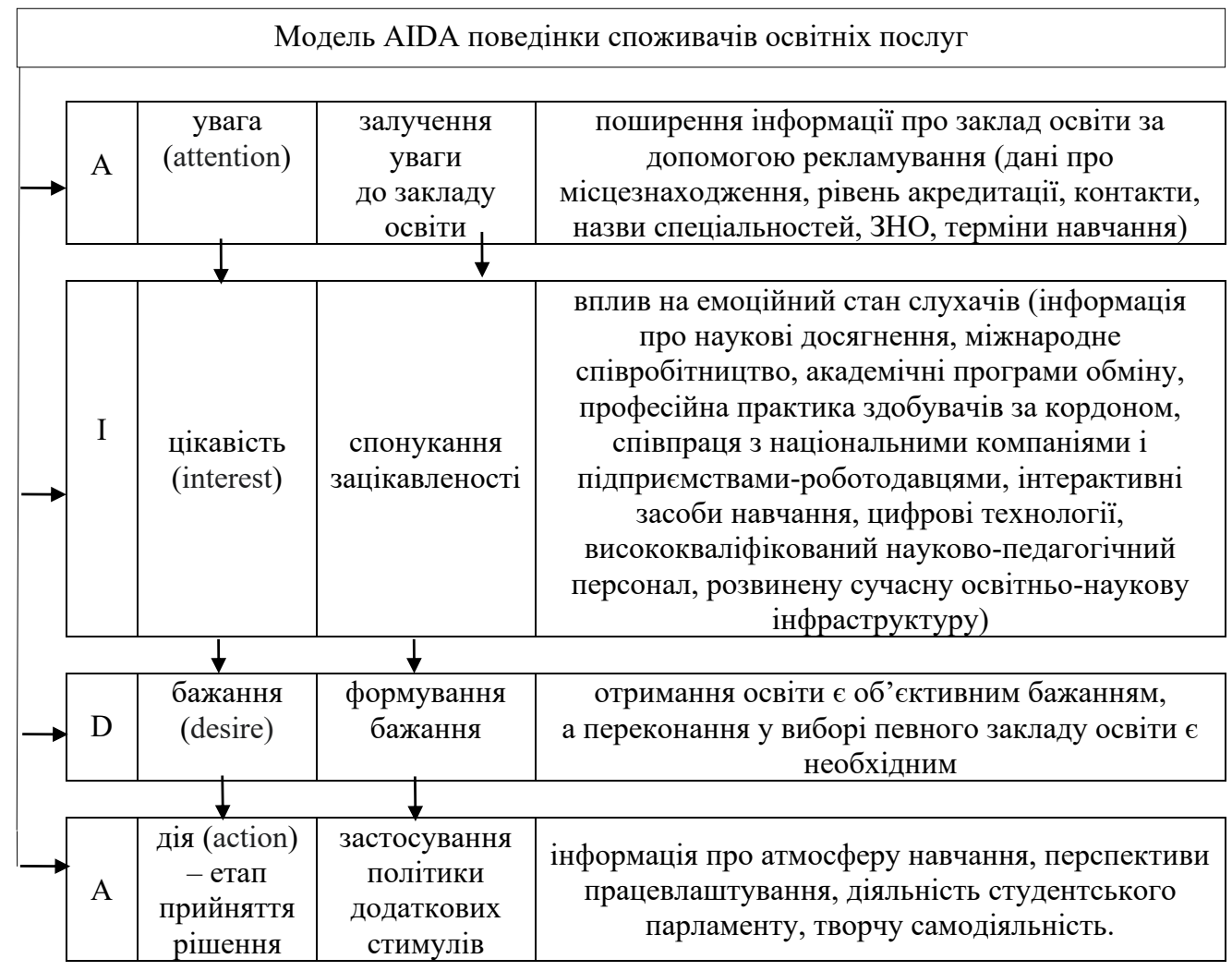

Рис. 1. Модель AIDA поведінки споживачів освітніх послуг

Джерело: узагальнено автором (Костюченко, 2011: 48-49; Могилова \& Решетнікова, 2016: 24)

Стратегічні орієнтири щодо освітніх послуг у закладах освіти першочергово формуються керівником за допомогою певної траєкторії. Зрозуміло, що найбільш поширеними є різні стратегії позиціонування. До групи факторів, які впливають на прийняття рішення, входять найважливіші основні запитання, які турбують як абітурієнтів, так і батьків, а саме: якість навчання, оплата освітніх послуг, місце знаходження і транспортне розташування, наявність гуртожитків, спортивних комплексів і творчої самодіяльності.

Оскільки одним із важливих завдань сайтів навчальних закладів $\epsilon$ активізація інтересу зі сторони абітурієнтів, О.А. Головко у науковій публікації «Інструменти залучення абітурієнтів на сайтах кафедр ВНЗ» (Головко, 2020: 40) пропонує використовувати модель споживчої поведінки AIDA для оцінки ефективності сайту кафедри як засобу залучення цільової аудиторії. Під інструментами інтернет-залучення абітурієнтів науковець розглядає різні форми інтерактивної взаємодії, наприклад такі, як онлайн-вікторини, конкурси, онлайн-тестування на визначення професії (залежно від напряму кафедри).

Науковець пропонує на сайтах кафедр закладів освіти розміщувати стрічки новин; спеціальну вкладку (піддомен) для абітурієнтів: перелік і опис спеціальностей кафедри; віртуальний тур по кафедрах; знайомство із викладачами; спеціальні події і заходи кафедр для абітурієнтів; онлайн-реєстрація на події та заходи; кнопки інтерактивної взаємодії; знижки на навчання, подарунки тощо (Головко, 2020: 43).

Науковці підтримують ідею застосування у навчальних закладах концепції холістичного маркетингу як моделі цілісного планування, розроблення і впровадження маркетингових програм і заходів, що включає чотири такі компоненти, як:

- внутрішній маркетинг (окремі викладачі, працівники; підрозділи навчального закладу; керівники вищої ланки); 
- маркетинг стосунків (споживачі освітніх послуг; партнери в каналах розподілу і комунікаційних каналах; контактні аудиторії);

- маркетинг-мікс (канали комунікації і розподілу на дистанційне навчання та філії; ціна, освітні послуги);

- соціально-етичний маркетинг (суспільство, право, етика, екологія) (Брітченко \& Чайкіна, 2011; Лилик, 2011: 55; Чайка, 2016: 219).

У практичній діяльності філософія холістичного маркетингу забезпечує розвиток демократії, децентралізацію влади, розвиток ініціативи «знизу», залучення до прийняття управлінських рішень усіх учасників освітнього процесу (Брітченко \& Чайкіна, 2011; Лилик, 2011: 55; Чайка, 2016: 219-221).

Для розширення можливостей надання освітніх послуг також варто впроваджувати концепцію Smartуніверситету, в основу якої покладено віртуальний освітній простір (Тягунова, 2016: 189). У свою чергу віртуальний простір закладів совіти уже став тим елементом, який може інтегрувати маркетингові інформаційно-комунікаційні можливості та зусилля у єдину комунікаційну стратегію, котра буде переважно зорієнтована на використання малобюджетних digital-комунікаційних технологій та інструментів (Тягунова, 2016: 189).

Для того, щоб визначитися, як правильно та ефективно спланувати мету діяльності закладу освіти, необхідно сформувати маркетингову стратегію позиціонування. Варто також розробити комунікаційну стратегію, що є документом про бізнес-цілі на довгострокову перспективу, аналіз поточного місця в комунікаційному просторі, методи та інструменти з урахуванням як поведінкових, так і соціальних змін.

У сучасному інформатизованому середовищі актуальними є три цифрові маркетингові стратегії:

- просування в пошукових системах;

- онлайн-реклама;

- маркетинг у соціальних мережах.

Особливо ефективними є діджитал-комунікації, а також низка підходів і показників ефективності онлайн-комунікацій, які за допомогою інформаційних технологій та діджитал-медіа мають прямий вплив на спілкування зі споживачами. Поряд ыз цим для залучення як реальних, так і потенційних споживачів нами розроблено маркетингову діджитал-стратегію (marketing digital strategy (MDS) позиціонування закладу освіти. В основі такої стратегії лежить створення сприятливого інформаційного середовища закладу освіти в мережі Internet, що буде демонструвати всі аспекти його діяльності. Таким чином, закладу освіти спочатку потрібно:

- розробити ефективний web-сайт;

- визначити, які ресурси потрібно залучити із Internet;

- розпочати поширення інформації через соціальні media;

- провести вступну online-кампанію.

Розроблення маркетингової діджитал-стратегії (MDS) включає чотири етапи (рис. 2):

- етап 1 - формування бізнес-цілей;

- етап 2 - визначення цільової аудиторії та концентрація на ній;

- етап 3 - визначення діджитал-тактики: 1) органічної (органічні соціальні медіа, еmail-маркетинг, SEO (Search Engine Optimization) як комплексу робіт, спрямованого на покращення сайту для його ранжування в пошукових системах за результатами видачі в цих пошукових системах; 2) платної (платний пошук, платні соціальні медіа);

- етап 4 - вимірювання ключових показників ефективності, аналіз результатів і формулювання висновків.

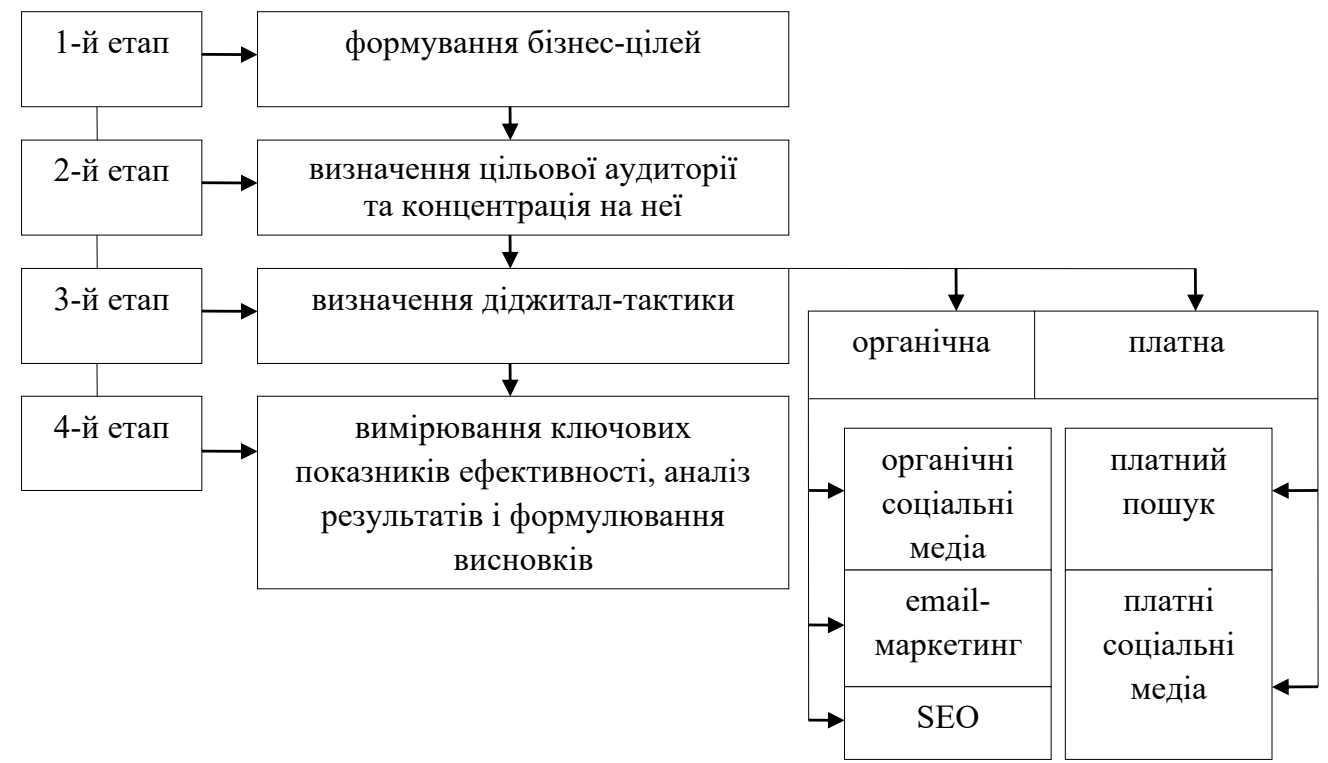

Рис. 2. Етапи формування маркетингової діджитал-стратегії (MDS) 
Таким чином, маркетингова діджитал-стратегія (marketing digital strategy (MDS) позиціонування закладу освіти, в основі якої лежить створення сприятливого інформаційного середовища закладу освіти в мережі Internet, демонструє всі аспекти діяльності закладів ЗВО. Насамперед закладу освіти потрібно: розробити ефективний web-сайт; визначити, які ресурси потрібно залучити із мережі Internet; розпочати поширення інформації через соціальні media; провести online-презентації.

Швидкі темпи інформатизації, формування веб-спільности, розгалудження Всесвітньої паутини (WWW, Word Wide Web) вимагають від закладів освіти розроблення власних офіційних веб-ресурсів 3 елементом «зворотний зв'язок», зорієнтованих на цільову аудиторію споживачів.

Науковці, реагуючи на сучасні виклики часу, вже розробили лінгвістичні методи і засоби планування освітніх послуг із використанням веб-спільноти, що дають змогу:

- освоїти архітектуру інформаційної системи опрацювання освітнього інформаційного наповнення для прогнозування контингенту здобувачів закладами освіти (Шілінг, 2019: 13);

- зрозуміти типові поведінки користувачів освітніх веб-спільнот і модель поведінки закладів освіти на основі запитів потенційних споживачів освітніх послуг (Шілінг, 2019: 15).

У своїй монографії «Діджиталізація світового ринку праці» С.І. Туль та О.В. Шкурупій (Туль \& Шкурупій, 2020: 52) констатують, що критерієм змін у межах системної трансформації суспільства $є$ ступінь поширення інтелектуального виробництва та інтелектуалізації суспільної діяльності. О. Піщуліна у своєму виданні «Цифрова економіка: тренди, ризики та соціальні детермінанти» вважає діджиталізацію і створення штучного інтелекту новим драйвером (Пищуліна, 2020: 27). Згідно з висновками PwC (AI Predictions, 2019), зробленими у 2019 р., у результаті застосування штучного інтелекту глобальний ВВП збільшиться на 14\% до 2030 р.

Управління маркетингом освітніх послуг як напрям в управлінській діяльності закладів освіти потребує наукового та прикладного обгрунтування. Нині він ще не достатньо розвинутий. В Україні в багатьох закладах освіти відсутні підрозділи маркетингу або відділи зв'язку із громадськістю. Маркетингову діяльність здійснюють в основному працівники приймальної комісії, які мають певні обмеження в часі.

Із структурно-організаційної позиції маркетингова орієнтація закладу освіти проявляється у створенні:

- відділу маркетингу (Котлер \& Армстронг, 2003: 49);

- департаменту маркетингу, який буде виконувати функції активної комунікаційної діяльності, розроблення і впровадження заходів щодо створення і підтримання відповідного іміджу закладу освіти, виявлення освітніх послуг, що вже користуються і будуть користуватися попитом на ринку, обгрунтування цін на освітні послуги з урахуванням величини і динаміки платоспроможного попиту, контроль за виконанням розроблених рекомендацій іншими підрозділами (Могилова \& Решетнікова, 2016);

- маркетингової служби (Птащенко \& Камінський, 2016: 184; Тягунова, 2016);

- служби маркетингового менеджменту, які б забезпечували ефективність та якість надання навчальним закладом комплексу освітніх послуг для задоволення потреб споживачів;

- центру зі збору маркетингової інформації (Тягунова, 2016: 194);

- загальноуніверситетської служби маркетингу (Тягунова, 2016);

- відділи з маркетинговими функціями (Чайка, 2016: 233).

Отже, для закладів освіти актуальним є посилення роботи вже наявних служб чи відділів маркетингу або створення служби маркетингового менеджменту. Адже в умовах формування ринку освітніх послуг іiі працівники будуть вирішувати нагальні проблеми, пов’язані з управлінням розвитком навчальних закладів, сегментацією ринку, асортиментом освітніх послуг, комунікаціями та іншими формами їх просування із врахуванням специфіки освітніх послуг і вітчизняного ринку праці.

Функціонування такої служби дасть змогу покращити роботу організаційної та управлінської структури закладу освіти, сформувати та оптимізувати маркетингову стратегію, спланувати й реалізувати тактику маркетингового менеджменту.

Оскільки основними видами діяльності служби маркетингового менеджменту є:

- аналітично-дослідницька (створення маркетингової інформаційної системи (МIC); маркетингові дослідження, аналіз рівня попиту і пропозиції на ринках праці та освітніх послуг, конкурентів; вивчення трудової мобільності, сприяння працевлаштуванню випускників, діяльність щодо підвищення їх конкурентоспроможності на ринку праці);

- комунікаційна (інформаційно-рекламне забезпечення; цілеспрямована й комплексна дія як на зовнішнє, так і на внутрішнє середовище навчального закладу для досягнення визначених стратегічних цілей і оперативних рішень; взаємодія між споживачами освітніх послуг, роботодавцями і стейкхолдерами);

- управління маркетингом (планування, прогнозування, організація, мотивація, контроль і корекція діяльності навчального закладу щодо виявлення і задоволення запитів споживачів із врахуванням цілей та їх можливостей).

Таким чином, основними критеріями щодо фахівців повинні стати: знання основ економіки і маркетингу, аналітичні здібності, вміння прогнозувати маркетингову ситуацію і приймати ефективні рішення, розробляти маркетингову стратегію для розвитку навчального закладу тощо. Також варто зазначити, що у багатьох випадках якість освіти визначається на рівні візуального усвідомлення.

Поряд із процесами автоматизації і діджіталізації провідне місце посідає автоматизація маркетингу. В умовах цифрової економіки звичні нам усім професійні вміння і навички будуть заміщуватися «м'якими навичками» (soft skills). Професійний світ майбутнього - це навички комплексного вирішення проблем, критичного і системного мислення, стрімкого розвитку особистості, а також вміння ставити незручні запитання. 
Найефективнішими інструментами і факторами формування іміджу закладу освіти у ХХІ ст. вважаються Smart-технології, які формують особливий інформаційний комунікативний простір, а саме:

- веб-сайт Wiki;

- інструменти та сервіси, мережеві додатки системи Google;

- звукові файли, ролики і відеоматеріали, аудіо- та візуальні презентації у глобальній мережі Internet;

- соціальні мережі Facebook, ВКонтакт, Twitter, Instagram;

- відоехостинги і блоги порталу Youtube;

- інші технологіï Web 2.0 (дозволяють використовувати мережеві спільноти для вільного поширення різної інформації, брати участь у нових заходах без спеціальних знань і навичок), зокрема різні види Sосіаl Media, технологіï Data Mining застосовуються в сегменті Smart-освіти.

Абітурієнти, вивчаючи пропозиції від закладів освіти, насамперед шукають Internet-сторінку того чи іншого закладу. Тому керівникам закладів освіти варто замислитися і переглянути політику щодо використання глобальної мережі Internet. Відповідно, дизайн Internet-сторінки повинен бути сучасним, оновленим і позитивно впливати на емоційний стан відвідувачів. Адже саме емоційний фактор забезпечує формування іміджу.

У сучасних умовах економічного і соціального розвитку світу процес побудови і розвитку іміджу багато в чому залежить від цінностей, що пропагуються у суспільстві в конкретний період часу. Зміни у сфері вищої освіти, необхідність швидкого реагування навчальними закладами на динаміку ринку ставлять перед закладами вищої освіти серйозні завдання щодо формування та реалізації іміджевої політики, стратегічного позиціонування і режиму відкритої взаємодії з громадськістю.

Однак те, що може бути застосовано до іміджу комерційних організацій, не переносилося до останнього часу в площину освітніх послуг. Введення рейтингу закладів вищої освіти (ЗВО) в Україні з метою визначення конкурентоспроможності освітніх послуг висунуло на перший план проблеми ведення іміджевої політики. Важливим для сприйняття і оцінки ЗВО є імідж, від якого залежить подальший успіх закладів освіти, зокрема й вищої.

До маркетингових аспектів підвищення якості вищої освіти в Україні входить активна робота 3 позиціонування закладів освіти, формування сприятливого іміджу в очах громадськості та потенційних споживачів. Популярність будь-якого закладу освіти визначається ступенем обізнаності цільової аудиторії про його освітні програми, перелік спеціальностей, основні завдання та успіхи. Найважливішу роль в цьому процесі відіграють маркетингові заходи, які є важливою складовою частиною іміджу закладів освіти.

Висновки. Таким чином, виокремлено фактори, які впливають на прийняття рішення як абітурієнтів, так і батьків: якість навчання, оплата освітніх послуг, місце знаходження і транспортне розташування, наявність гуртожитків, спортивних комплексів і творчої самодіяльності.

3'ясовано, що науковці підтримують ідею застосування у навчальних закладах концепції холістичного маркетингу як моделі цілісного планування, розроблення і впровадження маркетингових програм i заходів, що включає чотири такі компоненти: внутрішній маркетинг (окремі викладачі, працівники; підрозділи навчального закладу; керівники вищої ланки); маркетинг стосунків (споживачі освітніх послуг; партнери в каналах розподілу і комунікаційних каналах; контактні аудиторії); маркетинг-мікс (канали комунікації і розподілу на дистанційне навчання та філії; ціна, освітні послуги); соціально-етичний маркетинг (суспільство, право, етика, екологія).

Концептуальні засади формування маркетингової діджитал-стратегії позиціонування закладу освіти, що включає чотири етапи: формування бізнес-цілей; визначення цільової аудиторії та концентрація на ній; визначення діджитал-тактики; вимірювання ключових показників ефективності, аналіз результатів і формулювання висновків.

Для закладів освіти актуальним є посилення роботи вже наявних служб чи відділів маркетингу або створення служби маркетингового менеджменту. Маркетинг освітніх послуг націлений не тільки на створення, успішне просування і реалізацію освітніх послуг закладу освіти, а і на отримання сприятливого соціального ефекту.

Перспективи подальших досліджень полягають у проведенні аналізу рівня якості освітніх послуг у вищих закладах освіти України.

\section{Список використаних джерел:}

1. Брітченко І.Г., Чайкіна І.П. Маркетинг як чинник підвищення ефективності функціонування вищого навчального закладу. Науковий вісник Ужгородського університету. Серія «Економіка». 2011. Вип. 33. С. $299-302$.

2. Головко О.А. Інструменти залучення абітурієнтів на сайтах кафедр ВНЗ. Обрії друкарства. 2020. № 1(8). С. 40-51.

3. Костюченко А.М. Специфіка маркетингу освітніх послуг та сучасних проблем освіти в Україні в умовах ринкового середовища. Вісник Дніпропетровського університету. Серія «Економіка». 2011. Вип. 5 (3). С. $43-49$.

4. Котлер Ф., Армстронг Г. Основи маркетинга; пер. с англ. [9-е изд.]. 2003. 1200 с.

5. Лилик С.В. Задоволеність споживачів освітніх послуг як мета і критерій ефективності навчальних закладів. Маркетинг в Україні. 2011. № 05-06 (69). С. 5-58.

6. Могилова А.Ю., Решетнікова І.В. Особливості маркетингу на ринку освітніх послуг. Науковий вісник Ужгородського національного університету. 2016. Вип. 10, Ч. 2. С. 21-25.

7. Пищуліна О. Цифрова економіка: тренди, ризики та соціальні детермінанти. К.: Центр Разумкова, Видавництво «Заповіт», 2020. 274 с.

8. Птащенко О.В., Камінський Б.Ю. Інноваційний маркетинг та менеджмент у системі вищої освіти. Соціально-економічний розвиток регіонів в контексті міжнародної інтеграції: Науковий журнал ХНТУ. 2016. № 22 (11). С. 59-62.

9. Туль С.І., Шкурупій О.В. Діджиталізація світового ринку праці: монографія. Полтава: ПУЕТ, 2020. 302 с. 
10. Тягунова Н.М. Стратегія розвитку ВНЗ: маркетинговий аспект. Маркетинг діяльність підприємств: сучасний зміст [монографія]; за ред. Н.В. Карпенко. Київ: Центр учбової літератури, 2016. С. 184- 196.

11. Чайка І.П. Холістичний маркетинг як фактор розвитку та поглиблення зв'язків і залежностей між освітнім, науковим, виробничим і фінансовим секторами суспільства. Маркетинг діяльність підприємств: сучасний зміст [монографія]; за ред. Н.В. Карпенко. Київ: Центр учбової літератури, 2016. С. 216-237.

12. Шілінг А.Ю. Лінгвістичні методи та засоби планування надання освітніх послуг з використанням веб-спілнот: автореф. дис. ... канд. техн. наук: 10.02.21. Львів: Львівська політехніка, 2019. 20 с.

13. 2019 AI Predictions. Six AI priorities you can’t afford to ignore. PwC. 2019. URL: https://www.pwc.com/us/en/services/ consulting/library/ artificial-intelligencepredictions-2019.html.

14. Bettiga D., Lamberti L. and Noci G. (2018). Investigating social motivations, opportunity and ability to participate in communities of virtual co-creation. International Journal of Consumer Studies, 42(1). S. 155-163. Doi: https://doi.org/ 10.1111/ijcs.12409.

15. Charitha Harshani Perera, Rajkishore Nayak and Long Thang Van Nguyen (2020) Social brand engagement and brand positioning for higher educational institutions: an empirical study in Sri Lanka. Journal of marketing for higher education. S. 1-18. Doi: https://doi.org/10.1080/08841241.2020.1841068.

16. Jamali D. and Karam C. (2018) Corporate social responsibility in developing countries as an emerging field of study. International Journal of Management Reviews, 20(1). S. 32-61. Doi: https://doi.org/10.1111/ ijmr.12112.

17. Kethüda Önder (2021) Positioning strategies and rankings in the HE: congruence and contradictions. Journal of Marketing for Higher Education. Published online: 25 Feb 2021. URL: https://www. tandfonline.com/. Doi: doi/abs/10.1080/088412 41.2021.1892899.

\section{References:}

1. Britchenko, I.G. and Chaikina, I.P. (2011). Marketynh yak chynnyk pidvyshchennya efektyvnosti funktsionuvannya vyshchoho navchal'noho zakladu. [Marketing as a factor in improving the efficiency of higher education]. Naukovyy visnyk Uzhhorods'koho universytetu. U., Vol. 33. P. 299-302 [in Ukrainian].

2. Golovko, O.A. (2020). Instrumenty zaluchennya abituriyentiv na saytakh kafedr VNZ [Tools for attracting applicants on the websites of university departments]. Obriyi drukarstva. K., Vol. 1(8). P. 40-51 [in Ukrainian].

3. Kostyuchenko, A.M. (2011). Spetsyfika marketynhu osvitnikh posluh ta suchasnykh problem osvity v Ukrayini v umovakh rynkovoho seredovyshcha [Specifics of marketing of educational services and modern problems of education in Ukraine in the market environment]. Visnyk Dnipropetrovs'koho universytetu. D., Vol. 5(3). P. 43-49 [in Ukrainian].

4. Kotler, F. and Armstrong, G. (2003). Osnovy marketynha [Fundamentals of Marketing]. Izdatel'skiy dom "Vil'yame". M. [in Russian].

5. Lilik, S.V. (2011). Zadovolenist' spozhyvachiv osvitnikh posluh yak meta i kryteriy efektyvnosti navchal'nykh zakladiv [Satisfaction of consumers of educational services as a goal and criterion of efficiency of educational institutions]. Marketynh v Ukrayini. K., Vol. 05-06(69), P. 5-58 [in Ukrainian].

6. Mogilova, A.Y. and Reshetnikova, I.V. (2016). Osoblyvosti marketynhu na rynku osvitnikh posluh [Features of marketing in the market of educational services]. Naukovyy visnyk Uzhhorods'koho natsional'noho universytetu. U., Vol. 10, P. 2, S. 21-25 [in Ukrainian].

7. Pyshchulina, O. Tsyfrova ekonomika: trendy, ryzyky ta sotsial'ni determinant [Digital economy: trends, risks and social determinants]. K.: Tsentr Razumkova, Vydavnytstvo «Zapovit», 2020. 274 s. [in Ukrainian].

8. Ptashchenko, O.V. and Kaminsky, B.Yu. (2016). [Innovative marketing and management in the higher education system. Socio-economic development of regions in the context of international integration]. Naukovyy zhurnal KHNTU. Kh., Vol. 22(11). P. 59-62 [in Ukrainian].

9. Tul, S.I. and Shkurupiy, O.V. (2020). Didzhytalizatsiya svitovoho rynku pratsi [Digitalization of the world labor market], PUET, P. [in Ukrainian].

10. Tyagunova, N.M. (2016). Stratehiya rozvytku universytetu: marketynhovyy aspekt [University development strategy: marketing aspect]. Tsentr uchbovoyi literatury. K. [in Ukrainian].

11. Chaika, I.P. (2016). "Holistic marketing as a factor in the development and deepening of links and dependencies between the educational, scientific, industrial and financial sectors of society", Marketynh diyal'nist' pidpryyemstv: suchasnyy zmist, Center for Educational Literature. K. [in Ukrainian].

12. Schilling, A.Yu. (2019). "Linguistic methods and tools for planning the provision of educational services using the web together" Cand. tech. Science, structural, applied and mathematical linguistics, Lviv Polytechnicю L. [in Ukrainian].

13. 2019 AI Predictions. Six AI priorities you can't afford to ignore. PwC (2019). URL: https://www.pwc.com/us/en/services/ consulting/library/ artificial-intelligencepredictions-2019.html.

14. Bettiga, D., Lamberti, L. and Noci, G. (2018). Investigating social motivations, opportunity and ability to participate in communities of virtual co-creation. International Journal of Consumer Studies, 42(1). S. 155-163. https://doi.org/10.1111/ ijcs.12409.

15. Charitha Harshani Perera, Rajkishore Nayak and Long Thang Van Nguyen (2020). Social brand engagement and brand positioning for higher educational institutions: an empirical study in Sri Lanka. Journal of marketing for higher education. S. 1-18. DOI: https://doi.org/10.1080/08841241.2020.1841068.

16. Jamali, D. and Karam, C. (2018). Corporate social responsibility in developing countries as an emerging field of study. International Journal of Management Reviews, 20(1). S. 32-61. DOI: https://doi.org/10.1111/ijmr.12112.

17. Kethüda Önder (2021). Positioning strategies and rankings in the HE: congruence and contradictions. Journal of Marketing for Higher Education. Published online: 25 Feb 2021. URL: https://www.tandfonline.com. DOI: doi/abs/10.1080/08841241.2021. 1892899 . 